\title{
Direct Regeneration of Plants Derived from in vitro Cultured Shoot Tips and Leaves of Poplar (Populus $x$ euramericana 'Neva')
}

\author{
Chaoqiang Jiang ${ }^{1}$, Zhaopu Liu ${ }^{2}$ and Qingsong Zheng ${ }^{2}$ \\ 1. Tobacco Research Institute, Anhui Academy of Agricultural Sciences, Hefei 230031, Anhui, China \\ 2. College of Resources and Environmental Sciences, Nanjing Agricultural University, Nanjing 210095, Jiangsu, China
}

\begin{abstract}
The purpose of the present study was to establish a regeneration procedure for Populus $\times$ euramericana 'Neva' by using in vitro shoots tips and leaves. For sterilization, $0.1 \%(\mathrm{w} / \mathrm{v})$ mercuric chloride $\left(\mathrm{HgCl}_{2}\right)$ solution for 8 to 10 min was the optimal treatment for this poplar cultivation. The effects of benzyladenine (BA) and $\alpha$-naphthaleneacetic acid (NAA) added to Murashige and Skoog (MS) medium were tested on organogenesis. The highest regeneration rate and numbers of shoots/explant from shoot tips $(96.7 \%, 9.8)$ and leaves $(90.0 \%, 8.7)$ were obtained on the half-strength MS medium supplemented with $0.5 \mathrm{mg} / \mathrm{L} \mathrm{BA}$ and $0.1 \mathrm{mg} / \mathrm{L}$ NAA. The optimal medium for in vitro rooting of shoots was on a half-strength MS medium containing $1 \mathrm{mg} / \mathrm{L}$ indolebutyric acid (IBA) with the highest rooting frequency (93.3\%) and numbers of roots/explant (8.2). For acclimatization, in vitro rooted plantlets were transferred to plastic cups containing vermiculite and peat (1: 1). After acclimatization, transplanted plantlets grew well in a shade house. Therefore, we believe that this efficient plant regeneration protocol especially by leaf explants is very important for in vitro clonal propagation of Populus $\times$ euramericana 'Neva'.
\end{abstract}

Key words: Poplar (Populus $\times$ euramericana 'Neva'), In vitro culture, adventitious shoot, rooting, micropropagation.

\section{Introduction}

Poplars (genus Populus) are one of the most commercially exploited groups of forest trees that are widely distributed over the northern hemisphere and well known for their ecological, economical, and evolutionary importance $[1,2]$. They have been proposed as model systems for studying the trees biology because of their quick growth, ease of propagation, considerable genetic variation, small genome size, and transformability [3]. Populus $\times$ euramericana 'Neva' is a hybrid poplar (Populus nigra $\times$ Populus deltoids), and is one of the most important tree species for afforestation in north China due to its highly valuable characteristics such as fast growth, high resistance, and fine timber qualities. However, the productivity of this fast-growing poplar

Corresponding author: Chaoqiang Jiang, Ph.D., research field: plant nutrition and effective fertilization. E-mail: chaoqjiang@163.com. is usually restricted by soil salinity. Thus, antecedent salt tolerance of Populus $\times$ euramericana 'Neva' must be improved [2]. Genetic engineering is useful for reducing the time required for improving traits in plants and enhancing environmental adaptability $[4,5]$. Salt-tolerance breeding has achieved some progress through introducing salt-tolerant genes into plants [6], and genetic engineering appears to be an effective approach to enhance salt tolerance of poplar [2]. In vitro culture offers a basal system for micropropagation and genetic improvement.

For in vitro culture, selection of the appropriate explants is critical if an optimum number of rootable shoots are to be obtained. Modified Murashige and Skoog (MS) medium is frequently used for rapid propagation of poplar [7]. Benzyladenine (BA) together with $\alpha$-naphthaleneacetic acid (NAA) was used for shoot regeneration [8]. Rooting of regenerated shoots is a critical step in the production 
of complete plants. However, adventitious root formation is difficult for many plant species $[9,10]$. Low levels of indolebutyric acid (IBA) and NAA were used for the rooting of the microshoots [11]. Moreover, IBA is now used commercially worldwide to root many plant species $[12,13]$.

Nowadays, many studies involve tissue culture of many plant species [7, 8, 11-14]. Nevertheless, reliable and efficient methods of micropropagation and in vitro regeneration on Populus $\times$ euramericana 'Neva' are still lacking. Although, in vitro regeneration had been experimented by using three-week-old stem-segments and petioles of Populus $\times$ euramericana 'Neva' as explants [15], little has been reported about tissue culture of this species. Yet no direct leaf regeneration system on Populus $x$ euramericana 'Neva' has been reported to our knowledge. Leaves can provide more explants than the stem-segments and petioles in the same plant. The lack of organogenesis protocol is a serious hindrance for genetic engineering. Therefore, the purpose of the present study was to investigate a direct shoot and leaf regeneration of the Populus $\times$ euramericana 'Neva' by in vitro cultured explants. Some of this regeneration protocol has been successfully used in this species salt genetic transformation in our previous research $[2,16]$.

\section{Materials and Methods}

\subsection{In vitro culture Establishment}

Populus $\times$ euramericana 'Neva', maintained in a nursery under natural conditions, were used as the source of explants. Collected apical shoots (3.0 to 5.0 $\mathrm{cm})$ were washed first under running tap water containing $0.02 \%$ Tween $80(\mathrm{v} / \mathrm{v})$ for 20 min with stirring $(120 \mathrm{rpm})$, and then immersed in $70 \%(\mathrm{v} / \mathrm{v})$ alcohol for $30 \mathrm{~s}$ before surface sterilization in $0.1 \%$ (w/v) mercuric chloride $\left(\mathrm{HgCl}_{2}\right)$ solution for $6,8,10$ or $12 \mathrm{~min}$. After being washed 4 times with sterile distilled water, shoot tips $(0.5$ to $0.8 \mathrm{~cm})$ and nodal segments $(0.8$ to $1.0 \mathrm{~cm})$ were excised and placed onto
MS medium (Murashige and Skoog, 1962) containing half-strength macronutrients with $3 \%$ sucrose and $0.7 \%$ agar (1/2 MS). Every medium used in this study was adjusted to $\mathrm{pH} 5.8$. About $30 \mathrm{~mL}$ of medium was dispensed into $200 \mathrm{~mL}$ glass jars and autoclaved at $120{ }^{\circ} \mathrm{C}$ for $20 \mathrm{~min}$. All the cultures were kept in a growth chamber at $25{ }^{\circ} \mathrm{C}$ and $65 \%$ relative humidity under a $16 / 8 \mathrm{~h}$ photoperiod with light provided by fluorescent tubes at a photon flux density of 30 to 40 $\mu \mathrm{mol} / \mathrm{m}^{2} \cdot \mathrm{s}$. Explants were subcultured on the same medium at 2-week intervals. After 6 weeks of culture, the explants developed into $3.0-5.0 \mathrm{~cm}$ shoots, which were used for the following experiments.

\subsection{Direct Regeneration from Shoot Tips and Leaves}

The effects of the combination of benzyladenine (BA) and $\alpha$-naphthaleneacetic acid (NAA) on shoot initiation from shoot tips and leaves of Populus $\times$ euramericana 'Neva' were examined. Once the in vitro shoots reached a length of 3.0 to $5.0 \mathrm{~cm}$, they were excised and cut into about $1.0 \mathrm{~cm}$ length, and then placed onto MS medium supplemented with a combination of various BA $(0.1,0.5,1.0 \mathrm{mg} / \mathrm{L})$ and NAA $(0.05,0.1,0.2 \mathrm{mg} / \mathrm{L})$ for induction of multiple shoots. The expanded leaves from the shoot cultures were used as the source of explants. For shoot organogenesis, leaves along with a portion of petiole were excised and then cultured on MS medium containing BA $(0.1,0.5$, or $1.0 \mathrm{mg} / \mathrm{L})$ and NAA $(0.05$, 0.1 , or $0.2 \mathrm{mg} / \mathrm{L}$ ) with their petioles and abaxial sides in contact with the medium. All the explants were cultured at 22 to $25{ }^{\circ} \mathrm{C}$ and $65 \%$ relative humidity under a $16 \mathrm{~h}$ photoperiod (30 to $40 \mu \mathrm{mol} / \mathrm{m}^{2} \cdot \mathrm{s}$ ). The induction rate and average number of regeneration shoots/explant were recorded after 4 weeks of culture.

\subsection{In vitro Rooting of Shoots}

To determine the effects of the different concentrations of IBA and NAA on rooting, the regenerated shoots ( $>3 \mathrm{~cm}$ height) were separated and transferred for rooting on half-strength MS medium 
with IBA $(0.5,1.0$, or $2.0 \mathrm{mg} / \mathrm{L})$ and NAA $(0.05,0.1$, or $0.2 \mathrm{mg} / \mathrm{L}$ ). For rooting studies, each treatment used at least 30 explants. Observations on the number of rooted shoots and the number of roots/shoot were recorded after 4 weeks of treatment.

\subsection{Acclimatization}

For acclimatization, after careful removal from the medium, rooted plants were washed thoroughly in running tap water to remove all traces of medium without damaging the roots and transferred to plastic cups containing vermiculite and peat (1: 1$)$. The plantlets were covered with transparent polythene covers and sprayed daily with water for at least 10 days to maintain temperature and high relative humidity. After emergence of 3 to 4 new leaves, the plants were transplanted in bigger pots containing vermiculite and peat (1:1) and kept in a shade house where they were observed for further growth. The survival percentage was recorded 30 days after transferring to the bigger pot.

\subsection{Statistical Analyses}

All the experiments were conducted using a randomized complete block design. They were repeated three times. Data were presented as mean \pm standard error. Statistical analyses were performed using one-way ANOVA with SPSS statistical software. Comparisons among the means to determine significant differences $(P<0.05)$ were completed using Duncan's multiple-range test.

\section{Results}

\subsection{Direct Organogenesis of Shoot tips and Leaves}

The explants were surface sterilized in $0.1 \%$ mercuric chloride $\left(\mathrm{HgCl}_{2}\right)$ solution for 6 to $12 \mathrm{~min}$ in different sterilization efficiencies (Table 1). Although, little of the explants were contaminated in the treatment for $12 \mathrm{~min}$, the browning increased significantly for this amount of treatment time. The highest survival rates $(82 \%)$ of the explants received for 8 or $10 \mathrm{~min}$. Therefore, a $0.1 \% \mathrm{HgCl}_{2}$ solution used for 8 to $10 \mathrm{~min}$ provided a level of surviving explants suitable for in vitro poplar culture.

\subsection{Direct Organogenesis of Shoot Tips and Leaves}

After 7 days of incubation, most explants of poplar elongated and became enlarged (Fig. 1A and 1B). The effects of combinations of BA and NAA were highly significant on shoot regeneration from the cutting end of shoot tips and leaves. The green shoots elongated up to 2.0 to $3.0 \mathrm{~cm}$ in height after 30 days of culture. Multiple shoots obtained in all concentrations showed more or less similar results with regard to the number of shoots produced per leaf or stem tip explants.

The induction rate and number of shoots per shoot tip $(96.7 \%, 9.8)$ and leaf $(90 \%, 8.7)$ on MS medium containing $0.5 \mathrm{mg} / \mathrm{L} \mathrm{BA}$ and $0.1 \mathrm{mg} / \mathrm{L}$ NAA were higher than the other treatments (Table 2). Shoots continued to grow rapidly and the leaves of the adventitious shoots were healthy with green color and lacked hyperhydricity symptom. However, some shoots

Table 1 Survival, rate of microbial contamination and browning of excised poplar shoots after surface sterilization in $0.1 \%$ mercuric chloride $\left(\mathrm{HgCl}_{2}\right)$ solution for different times.

\begin{tabular}{llll}
\hline Time $(\min )$ & Rate of contamination $(\%)$ & Rate of brown (\%) & Survival (\%) \\
\hline 6 & $24 \mathrm{a}$ & $2 \mathrm{c}$ & $74 \mathrm{~b}$ \\
8 & $10 \mathrm{~b}$ & $8 \mathrm{~b}$ & $82 \mathrm{a}$ \\
10 & $8 \mathrm{~b}$ & $10 \mathrm{~b}$ & $82 \mathrm{a}$ \\
12 & $4 \mathrm{~b}$ & $18 \mathrm{a}$ & $78 \mathrm{ab}$ \\
\hline
\end{tabular}

Mean values within a column followed by the same letter are not significant differences $(P \leq 0.05)$ according to Duncan's multiple-range test $(\mathrm{N}=50)$. 

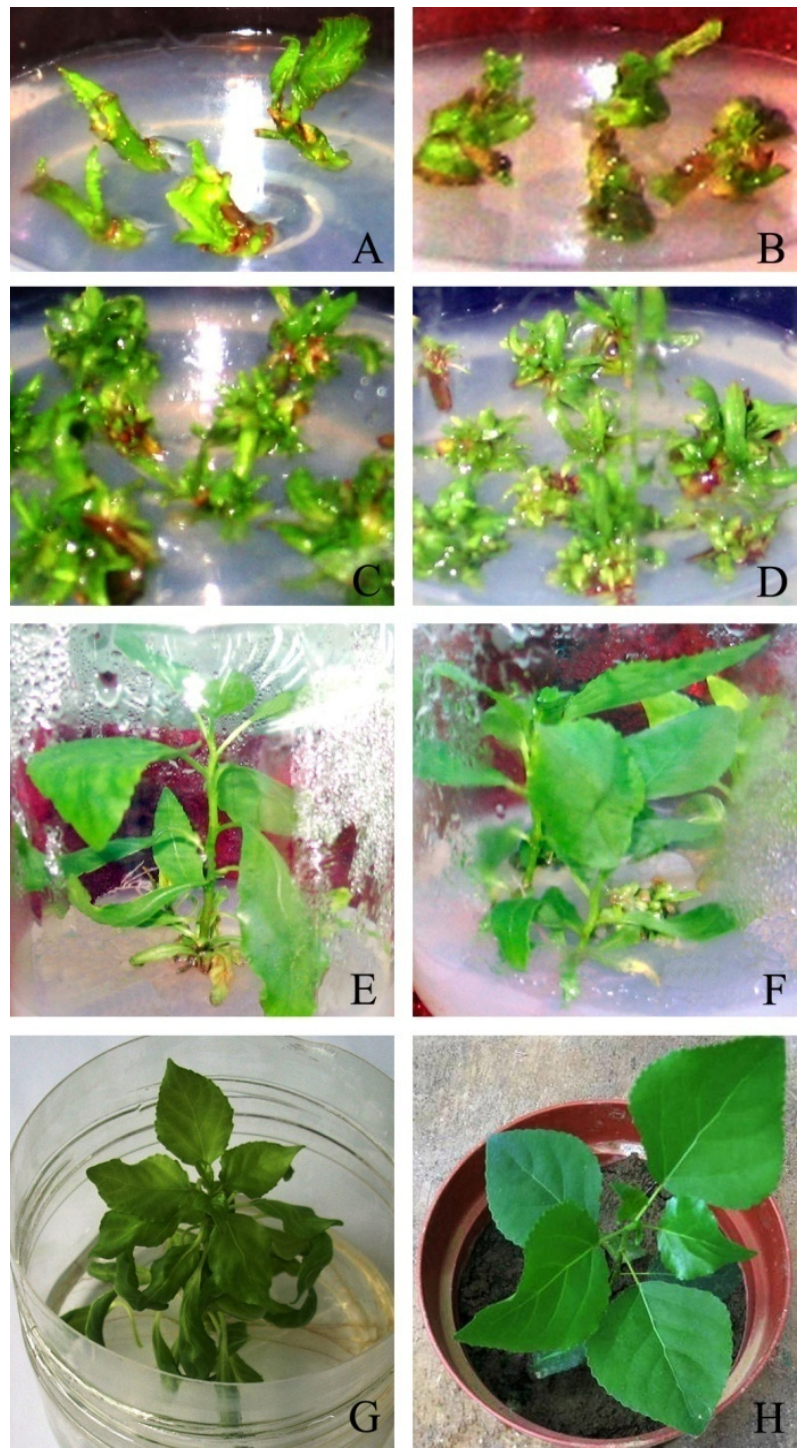

Fig. 1 Plant regeneration via culture of shoot tips and leaves from in vitro plantlet of Populus $\times$ euramericana 'Neva'.

(A, B) emergence of shoot buds from shoot tips and leaves after 7 days in culture, respectively, (C, D) adventitious shoots from shoot tips and leaves after 28 days in culture, respectively, (E, F) robust picture of the regeneration of adventitious shoots from shoot tips and leaves, respectively, $(\mathrm{G})$ rooted plantlets after 6 weeks on rooting medium, $(\mathrm{H})$ micropropagation plant in pot containing vermiculite and peat (1:1) after 30 days.

had hyperhydricity symptom when the BA concentration was up to $1.0 \mathrm{mg} / \mathrm{L}$, and increasing NAA concentrations reduced shoot production as well as increased callus formation. Thus, the medium supplemented with $0.5 \mathrm{mg} / \mathrm{L} \mathrm{BA}$ and $0.1 \mathrm{mg} / \mathrm{L}$ NAA was selected for direct regeneration of poplar, as the highest number of shoot formation and shoot growth were fairly good in this treatment (Fig. 1C and 1D).

\subsection{In vitro Rooting of Shoots}

Regenerated shoots could be excised into single shoots over several subcultures and transferred to root induction medium. All shoots developed roots from the cutting end of shoots after 2 weeks on rooting medium. After 4 weeks of culture, the mean root numbers per shoot differed significantly between the treatments. The results indicated that the rooting percentage was highest $(93.3 \%)$ on a $1 / 2 \mathrm{MS}$ medium supplemented with $1 \mathrm{mg} / \mathrm{L} \mathrm{IBA}$ among the different treatments (Table 3). Moreover, much more roots developed from the excised shoots on 1/2 MS medium containing $1 \mathrm{mg} / \mathrm{L} \mathrm{IBA}$, and the roots were healthy, thick, long and fibrous. Thus, half-strength MS medium supplemented with $1 \mathrm{mg} / \mathrm{L}$ IBA was effective for root induction.

\subsection{Acclimatization of Regenerated Plantlets}

Rooted plantlets with three to four fully expanded leaves and well-developed roots were successfully transferred to pots containing vermiculite and peat (1: 1). New growth of the potted plants was observed by $30 \mathrm{~d}$ after transfer. More than eighty percent of the rooted plantlets survived after transplanting into soil in the greenhouse. Transplanted and acclimatized plantlets grew normally without showing any visible variation in morphological or growth characteristics compared with the donor plants (Fig. 1H).

\section{Discussion}

A lack of reliable and reproducible tissue culture protocols for regenerating plants from transformed cells is a major hindrance for successful genetic engineering.

Microshoot proliferation was a crucial step for in vitro culture of poplar since it directly determined the feasibility of mass micropropagation. Explants treatment with different plant growth regulators is an 
Table 2 Effect of various combinations of BA and NAA on adventitious shoot regeneration from shoot tips and leaves explants of poplar.

\begin{tabular}{llllll}
\hline $\begin{array}{l}\text { BA } \\
(\mathrm{mg} / \mathrm{L})\end{array}$ & $\begin{array}{l}\text { NAA } \\
(\mathrm{mg} / \mathrm{L})\end{array}$ & $\begin{array}{l}\text { Shoot tip } \\
\text { Mean shoot number } \\
\text { per explant }\end{array}$ & $\begin{array}{l}\text { shoot induction } \\
(\%)\end{array}$ & $\begin{array}{l}\text { Leaf } \\
\text { Mean shoot number } \\
\text { per explant }\end{array}$ & $\begin{array}{l}\text { shoot induction } \\
(\%)\end{array}$ \\
\hline 0 & 0 & $3.2 \mathrm{f}$ & $30.0 \mathrm{~d}$ & $2.0 \mathrm{f}$ & $20.0 \mathrm{e}$ \\
\hline 0.1 & & $4.1 \mathrm{e}$ & $56.7 \mathrm{c}$ & $3.1 \mathrm{e}$ & $43.3 \mathrm{~d}$ \\
0.5 & 0.05 & $5.5 \mathrm{c}$ & $73.3 \mathrm{~b}$ & $4.6 \mathrm{c}$ & $66.7 \mathrm{~b}$ \\
1 & & $4.9 \mathrm{~d}$ & $56.7 \mathrm{c}$ & $4.2 \mathrm{c}$ & $60.0 \mathrm{bc}$ \\
\hline 0.1 & & $5.8 \mathrm{c}$ & $80.0 \mathrm{~b}$ & $4.7 \mathrm{~cd}$ & $66.7 \mathrm{~b}$ \\
0.5 & 0.1 & $9.8 \mathrm{a}$ & $96.7 \mathrm{a}$ & $8.7 \mathrm{a}$ & $90.0 \mathrm{a}$ \\
1 & & $7.0 \mathrm{~b}$ & $86.7 \mathrm{ab}$ & $5.9 \mathrm{~b}$ & $70.0 \mathrm{~b}$ \\
\hline 0.1 & & $4.4 \mathrm{de}$ & $53.3 \mathrm{c}$ & $3.6 \mathrm{de}$ & $46.7 \mathrm{~cd}$ \\
0.5 & 0.2 & $7.2 \mathrm{~b}$ & $76.7 \mathrm{~b}$ & $6.1 \mathrm{~b}$ & $63.3 \mathrm{~b}$ \\
1 & & $5.6 \mathrm{c}$ & $73.3 \mathrm{~b}$ & $5.6 \mathrm{~b}$ & $60.0 \mathrm{bc}$ \\
\hline
\end{tabular}

Data recorded on the 28th day. Mean values within a column followed by the same letter are not significant differences $(\mathrm{p} \leq 0.05)$ according to Duncan's multiple-range test $(\mathrm{N}=30)$.

Table 3 Effects of IBA and NAA on rooting of in vitro poplar shoots that were formed on leaf explants.

\begin{tabular}{llll}
\hline IBA $(\mathrm{mg} / \mathrm{L})$ & NAA $(\mathrm{mg} / \mathrm{L})$ & Percentage of rooting $(\%)$ & Number of roots per shoot \\
\hline 0 & 0 & $16.7 \mathrm{e}$ & $2.2 \mathrm{e}$ \\
0.5 & & $70.0 \mathrm{c}$ & $4.8 \mathrm{c}$ \\
1 & & $93.3 \mathrm{a}$ & $8.2 \mathrm{a}$ \\
2 & $53.3 \mathrm{~d}$ & $4.5 \mathrm{c}$ \\
& 0.05 & $63.3 \mathrm{~cd}$ & $4.2 \mathrm{~cd}$ \\
& 0.1 & $83.3 \mathrm{~b}$ & $5.9 \mathrm{~b}$ \\
& 0.2 & $56.7 \mathrm{~cd}$ & $3.6 \mathrm{~d}$ \\
\hline
\end{tabular}

Data recorded on the 28th day. Mean values within a column followed by the same letter are not significant differences $(P \leq 0.05)$ according to Duncan's multiple-range test $(\mathrm{N}=30)$.

effective technique generally used for obtaining maximum results [17]. The auxin/cytokinin balance is one of the factors to increase the number of vegetative shoots because it has a decisive effect morphogenesis from explants. And the combinations of BA and NAA have proven to be beneficial, especially in the quality improvement of the shoots produced $[8,18]$. In the present study, the best combination of BA and NAA was crucial for direct shoot regeneration from axenic shoot tips and leaf explants. The results demonstrated that adventitious shoot reformed directly from in vitro-cultured shoot tips and leaves of poplar. The medium supplemented with $0.5 \mathrm{mg} / \mathrm{L}$ BA and 0.1 $\mathrm{mg} / \mathrm{L}$ NAA produced most shoots in all combination of BA plus NAA treatments in the present study, and subsequent shoot growth was fairly good in this treatment (Table 2). The results obtained here were similar to other studies where BA and NAA promoted the proliferation and elongation of shoots in buds from Lysimachia species [8]. Although, thidiazuron (TDZ) is more effective for shoot regeneration than BA for many woody species [19, 20]. Moreover, in our preparative experiment, we also used BA in a concentration up to $2.0 \mathrm{mg} / \mathrm{L}$, and NAA $1.0 \mathrm{mg} / \mathrm{L}$ to induce shoot regeneration from the explants. However, the regeneration capacity by using BA or NAA alone didn't work well (data not shown).

Rooting of regenerated shoots is the most decisive step in the production of complete plants and their subsequent survival in the soil. However, adventitious root formation is difficult on many plant species in vitro $[9,10]$. The growth dynamics of root formation depended on the auxin used. Among the auxins, IBA and NAA are the most frequently applied for rooting 
$[12,18]$. Moreover, IBA has been the subject of many experiments to achieve optimum rooting conditions, and the superior effect of IBA on root development has been previously documented in other plant species $[12,21]$. Here, we applied IBA for the successful root formation, in combination with half-strength MS mineral salts medium. In the present study, we applied either IBA or NAA for the successful root formation, in combination with half-strength MS medium. However, IBA was more effective than NAA in the production of long, slender and healthy roots. Half-strength MS medium supplemented with IBA (1 $\mathrm{mg} / \mathrm{L}$ ) induced the highest levels of root development and successful plant establishment (Table3, Fig. 1E). The superior effect of IBA on both root and shoot development has been previously documented for other plant species [12-14]. Primary and lateral root growth was promoted by IBA, whereas NAA strongly inhibited rooting of a Chinese medicinal plant, Ohwi (P. lobata) [22], and Karwinskia (K. humboldtiana) [23]. The superior effects of IBA on root formation by these plant species, including poplar, might be due to several factors, such as its preferential uptake, transport, and stability over NAA and subsequent gene activation [24]. However, NAA supported the formation of very short roots (data not shown), and fewer roots per shoot in this study. Ahn et al. [12] reported that IBA was more efficient in promoting root development, resulting in a higher rate of establishment (93.5\%) compared to the rate with NAA (39.5\%) in castor (Ricinus communis L.), which is similar to our results.

\section{Conclusions}

An efficient and reproducible regeneration protocol was established for Populus $\times$ euramericana 'Neva' by using in vitro shoot tips and leaves was developed on the basis of step-by-step experiments of culture induction, propagation and rooting. The highest regeneration rate and numbers of shoots/explant from shoot tips and leaves were obtained on the 1/2 MS medium supplemented with $0.5 \mathrm{mg} / \mathrm{L}$ BA and 0.1 $\mathrm{mg} / \mathrm{L} \mathrm{NAA}$, and the optimal medium for rooting of shoots was recorded on a $1 / 2$ MS medium containing $1 \mathrm{mg} / \mathrm{L} \mathrm{IBA}$ in the present study. This protocol makes this poplar culture a potential candidate for genetic transformation.

\section{References}

[1] Hamzeh, M., and Dayanandan, S. 2004. Phylogeny of Populus (Salicaceae) Based on Nucleotide Sequences of Chloroplast trnT-trnF Region and Nuclear rDNA. Am. J. Bot. 91: 1398-408.

[2] Jiang C. Q., Zheng, Q. S., Liu, Z. P., Liu, L., Zhao, G. M., Long, X. H., and Li, H. Y. 2011. Seawater-irrigation Effects on Growth, Ion Concentration, and Photosynthesis of Transgenic Poplar Overexpressing the $\mathrm{Na}^{+} / \mathrm{H}^{+}$ Antiporter AtNHX1. J. Plant Nutr. Soil Sci. 174: 301-10.

[3] Taylor, G. 2002. Populus: Arabidopsis for Forestry. Do We Need a Model Tree? Ann. Bot. 90: 681-9.

[4] Uzogara, S. G. 2000. The Impact of Genetic Modification of Human Foods in the 21st Century: A Review. Biotechnol. Adv. 18: 179-206.

[5] Azadi, H., and Ho, P. 2010. Genetically Modified and Organic Crops in Developing Countries: A Review of Options for Food Security. Biotechnol. Adv. 28: 160-8.

[6] Wang, W., Vinocur, B., and Altman, A. 2003. Plant Responses to Drought, Salinity and Extreme Temperatures: Towards Genetic Engineering for Stress Tolerance. Planta 218: 1-14.

[7] Peternel, Š., Gabrovšek, K., Gogala, N., and Regvar, M. 2009. In vitro Propagation of European Aspen (Populus tremula L.) from Axillary Buds via Organogenesis. Sci. Hort. 121: 109-12.

[8] Zheng, W., Xu, X. D., Dai, H., and Chen, L. Q. 2009. Direct Regeneration of Plants Derived from in vitro Cultured Shoot Tips and Leaves of Three Lysimachia Species. Sci. Hort. 122: 138-41.

[9] Davies, F. T. Jr., Davis, T. D., and Kester, D. E. 1994. Commercial Importance of Adventitious Rooting to Horticulture. In: Davis, T. D., Haissig, B. E. (eds.), Biology of Adventitious Root Formation. New York: Plenum Press, 53-9.

[10] Kovar, J. L., and Kuchenbuch, R. O. 1994. The Commercial Importance of Adventitious Rooting to Agronomy. In: Davis, T. D., Haissig, B. E. (eds.), Biology of Adventitious Root Formation. New York: Plenum Press, 25-34.

[11] Ahuja, M. R. 1983. Somatic Cell Differentiation and Rapid Clonal Propagation of Aspen. Silvae Genet. 32 (3/4): 131-5. 
(Populus x euramericana 'Neva')

[12] Ahn, Yeh-J., Vang, L., McKeon, T. A., and Chen, G. Q. 2007. High-frequency Plant Regeneration through Adventitious Shoot Formation in Castor (Ricinus communis L.). In Vitro Cell Dev-Pl. 43: 9-15.

[13] Sujatha, G., Jayabalan, N., and Ranjitha Kumari, B. D. 2007. Rapid in vitro Micropropagation of Cicer arietinum L. Hort. Sci. (Prague) 34: 1-5.

[14] Kim, M. S., Klopfenstein, N. B., and Cregg, B. M. 1998. In vitro and ex vitro Rooting of Micropropagated Shoots using Three Green Ash (Fraxinus pennsylvanica) Clones. New Forest 16: 43-57.

[15] Sun, Y. F., Gao, X. H., Zhao, Y. X., and Zhang, H. 2004. The Establishment of in vitro Regeneration System on Populus Populus $\times$ euramericana 'Neva'. J. of Shandong Normal University 19 (2): 85-7.

[16] Jiang, C. Q., Zheng, Q. S., Liu, Z. P., Xu, W. J., Liu, L., Zhao, G. M., and Long, X. H. 2011. Overexpression of Arabidopsis Thaliana $\mathrm{Na}^{+} / \mathrm{H}^{+}$Antiporter Gene Enhanced Salt Resistance in Transgenic Poplar (Populus $\times$ euramericana 'Neva'). Trees 26: 685-94.

[17] D'onofrio, C., and Morini, S. 2006. Somatic Embryo, Adventitious Root and Shoot Regeneration in in vitro Grown Quince Leaves as Influenced by Treatments of Different Length with Growth Regulators. Sci. Hort. 107: 194-9.
[18] Harry, I. S., and Thrope, T. A. 1994. In vitro Culture of Forest Trees. In: Vasil, I. K., Thrope, T. A. (eds.), Plant Cell and Tissue Culture. Kluwer Academic Publishers, Dodrecht, the Netherlands. 539-60.

[19] Huetteman, C. A., and Preece, J. E. 1993. Thidiazuron: A Potent Cytokinin for Woody Plant Tissue Culture. Plant Cell Tiss. Org. 33: 105-19.

[20] Bhagwat, B., and Lane, W. D. 2004. In vitro Shoot Regeneration from Leaves of Sweet Cherry (Prunus avium) 'lapins' and 'sweetheart'. Plant Cell Tiss. Org. 78: 173-81.

[21] Ludwig-Müller, J., Vertocnik, A., and Town, C. D. 2005. Analysis of Indole-3-butyric Acid-induced Adventitious Root Formation on Arabidopsis Stem Segments. J. Exp. Bot. 56: 2095-105.

[22] Liu, C., Zhu, J., Liu, Z., Li, L., Pan, R., and Jin, L. 2002. Exogenous Auxin Effects on Growth and Phenotype of Normal and Hairy Roots of Pueraria lobata (Willd.) Ohwi. Plant Growth Regul. 38: 37-43.

[23] Kollárová, K., Lišková, D., Kákoniová, D., and Lux, A. 2004. Effect of Auxins on Karwinskia humboldtiana Root Cultures. Plant Cell Tiss. Org. 79: 213-21.

[24] Ludwig-Müller, J. 2000. Indole-3-butyric Acid in Plant Growth and Development. Plant Growth Regul. 32: 219-30. 